\title{
Assessment of By-product Valorisation in a Swedish Wheat-Based Biorefinery
}

\author{
Linda Hagman $^{1}$ (D) Mats Eklund ${ }^{1} \cdot$ Niclas Svensson $^{1}$
}

Received: 2 November 2018 / Accepted: 25 March 2019 / Published online: 5 April 2019

(c) The Author(s) 2019

\begin{abstract}
Biorefineries are examples of industries striving towards a circular and bio-based economy through valorising natural raw materials to a spectrum of products. This is a resource-efficient process which also decreases overall environmental impact, as the products from a biorefinery can replace fossil-based products such as plastics or fuels. To become even more resource efficient, an optimisation of the by-product use can increase the performance. This study will evaluate different scenarios for the valorisation of stillage coming from a wheat-based biorefinery. The alternatives range from the direct use of the stillage for fodder, fertiliser or incineration to three different biogas production-based scenarios. The biogas scenarios are divided into the production of fuel at a local or distant plant and the alternative of creating heat and power at the local plant. The results show how locally produced biogas for vehicle fuel and fodder usage are the better alternatives regarding greenhouse gas emissions, the finances of the biorefinery, energy balance and nutrient recycling. The results also indicate that biorefineries with several high-value products may receive lower quality by-product flows, and to these, the biogas solutions become more relevant for valorising stillage while improving value and performance for the biorefinery.
\end{abstract}

\section{Graphical Abstract}

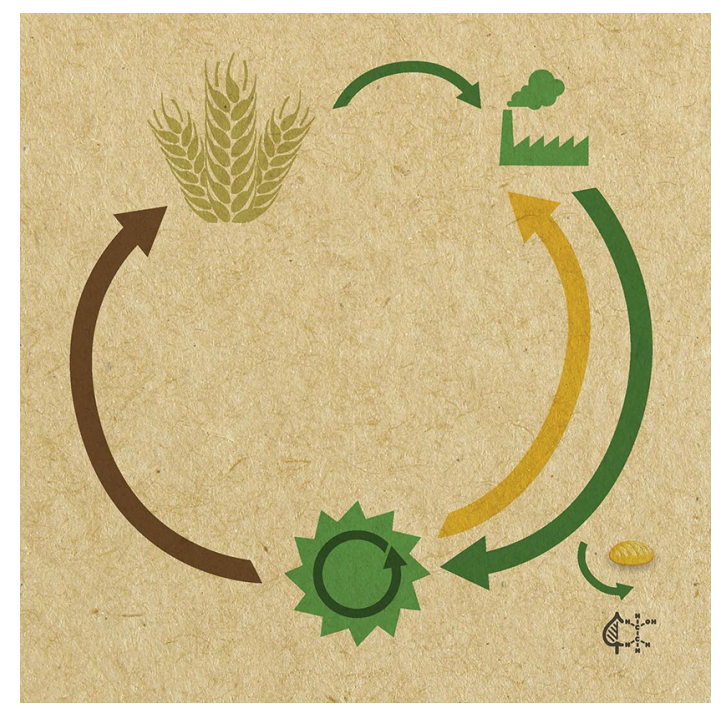

Keywords Biorefinery $\cdot$ Upcycling $\cdot$ Waste $\cdot$ Biogas $\cdot$ Fodder

Electronic supplementary material The online version of this article (https://doi.org/10.1007/s12649-019-00667-0) contains supplementary material, which is available to authorized users.

Extended author information available on the last page of the article 


\section{Statement of Novelty}

This research was undertaken as the importance of byproduct valorisation in biorefineries are not commonly assessed. The study also wanted to include estimations of nutrient recycling as it is important in biobased systems to take care of the nutrients in the biomass. The article point out the importance of broader assessments of biorefineries. This study has shown that biogas solutions contribute to nutrient recycling and are also a valorisation method which can be viable even if the quality of the by-product stream is poor.

\section{Introduction}

Efficient resource use in production facilities calls for optimisation of the entire product portfolio. Historically, businesses have typically focused on the process optimisation of one main product, while by-product valorisation often has been neglected. Thus, there is often an improvement potential in those flows. By-products can either be further valorised internally or through collaborative approaches with neighbouring independent actors. The latter, which represents a higher organisational complexity, is often termed industrial symbiosis.

Biorefinery concepts become more widespread [1] and include a more holistic solution including value creation from a range of by-products. The definition of a biorefinery formulated by the International Energy Agency (IEA) reads, "sustainable processing of biomass into a spectrum of marketable products (food, feed, materials and chemicals) and energy (fuels, power and heat)" [ [2], p. 2]. In the bio-based economy, industries can increase the overall performance of their main products by utilising by-products for further refinement in a biorefinery [3]. Upgrading raw materials to many different products is efficient both for the company's economy and the environment. However, this can be neglected due to the difficulties for companies to handle too many development projects, especially if they are outside their core business. Different actors can act together in a network of actors, but their joint function can be seen as one biorefinery system. Upcycling is a concept covering the processes when low valued byproduct streams are used to create products such as fodder or energy, providing more value for the business $[3,4]$.

The diversity of the product portfolio of a biorefinery is likely to vary over time, which depends on a certain resilience capacity of the system. Biorefinery development will typically generate a number of by-products with higher value. Thus, remaining by-product streams will often have low-quality for instance in terms of low nutrient content, low energy density or be technically hard to treat. Being able to successfully upcycle these materials can help sustain the biorefinery industry [5].

Biorefinery networks processing raw materials used for food are often situated near arable land, and they process food products and divert by-products to fodder production, biogas production or fertiliser in the nearby region. The agricultural sector is an important part of the bioeconomy. Food production faces many sustainability-related challenges. It relies on fossil inputs for mechanical treatment and fertilisers and creates pollution-related problems [6]. As transportation in the agricultural sector is fossil dependant, solutions for renewable options are important. Assessing sustainability in this sector calls for broader assessments that are for instance not neglecting the urgent nutrient supply issue [7]. Nutrients from by-products have the potential to improve the environmental performance of the production system [8] and are important in the circular economy [9]. Common treatments of agricultural low-value by-product streams in Sweden today are anaerobic digestion (up-graded to vehicle fuel and biofertiliser), fodder production, waste incineration with combined heat and power (CHP) and direct use as fertiliser [10].

When assessing the effects of different uses of by-product flows, it is important to apply a system perspective regarding the impact the different valorisation alternatives may have. To address this objective, a framework is developed where the studied alternatives also should be economically feasible for the biorefinery and develop upcycling pathways.

The aim of the current study is to analyse and understand what effects different uses of low-quality by-products in a wheat-based biorefinery have. In order to do that, a framework covering climate impact, energy and nutrient efficiency and finance is developed and applied to the study.

\section{Method}

This assessment is based on a real case of a Swedish wheatbased biorefinery. The biorefinery uses winter wheat as raw material and produces starch, gluten, ethanol, stillage and products refined into syrups in a different plant. Mapping of flows and actors involved has been important in the further assessments of the scenarios. The methodology illustrated in Fig. 1 shows how interviews, literature reviews and data collection have been used throughout the phases of the work. In Fig. 1, the chosen scenarios are shown but are further explained in "Scenario Descriptions and Data Collection" section. Scenarios as a method are useful when there are uncertainties regarding future developments [11]. In this case, alternative valorisations are possible and several predictive what-if scenarios with quantitative evaluation in a 
Fig. 1 Methodology flowchart

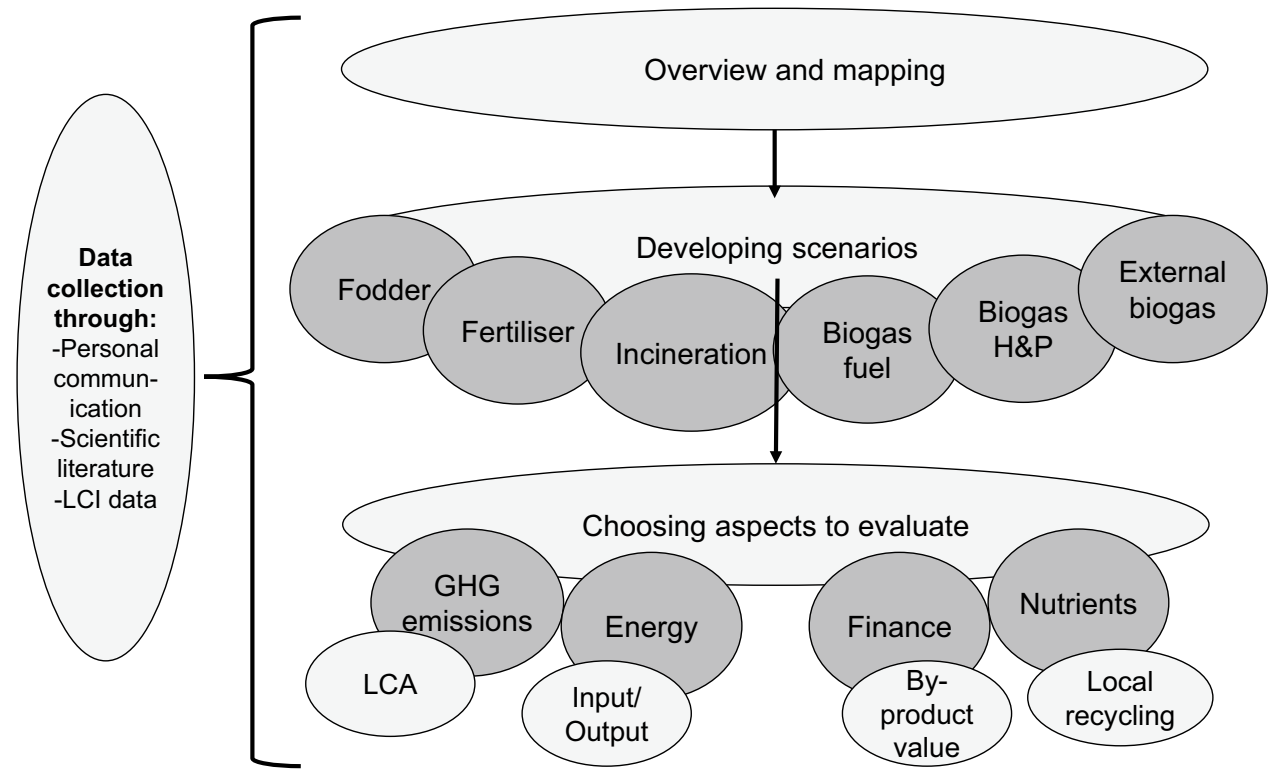

short time frame period are used. A predictive what-if scenario is designed towards alternatives that have not happened [12]. Each and every scenario is evaluated on four chosen aspects illustrated in Fig. 1, and the method corresponding to each aspect is seen in the figure. The motivation behind these aspects is connected to the environmental and financial performance of an industrial system. Climate impact, energy use and nutrient recycling will capture the environmental aspects of different scenarios, while the finances will show the feasibility for the biorefinery to choose a specific scenario. The aspects are further explained in "Evaluating Aspects" section.

To assess the different valorisation alternatives, a system analysis looking into several different aspects gives a broad picture. Similar studies to this have been done previously, but have not evaluated as many scenarios [13-16]. The focus here lies on upcycling low-qualitative by-product flows in a biorefinery setting, as few studies in this area have been identified in the literature.

In the end, a sensitivity analysis is performed based on parameters which are noted to be uncertain or have significant impact. The parameters will be chosen after the assessment is performed and will give alternative representations of the results.

\section{Case Description}

All the scenarios are based on a wheat-based biorefinery situated in a city with approximately 30,000 inhabitants in the middle of Sweden, in a region with farming activities. The biorefinery requires approximately 140,000 tonnes of winter wheat in its production, and the total amount of stillage produced is 210,000 tonnes; data regarding the characteristics are provided by the biorefinery company. During distillation, the mash of wheat and water is separated from the pure ethanol product. This mash, called stillage, has an average dry matter (DM) content of $8 \%$, as three stillage fractions are mixed. The stillage has a relatively low protein content of $17 \%$ per $\mathrm{kg}$ DM compared to other studies, where protein content ranges between 28 and $41 \%$ per kg DM [14]. A reason for this is the extraction of several high-value products in the studied biorefinery resulting in a low-quality stillage. There are still, however, several uses for the stillage, and it is worthwhile to evaluate which valorisation methods can improve the overall performance.

To compare the evaluated aspects in each scenario with each other, we assume all stillage produced is used for one single purpose. Transports are done by the same type of trucks in all scenarios as long as nothing else is mentioned. The emissions from the trucks are based on the size of the truck. Longer distances (further than $100 \mathrm{~km}$ ) are assumed to be heavier than 32 tonnes and emit $0.1119 \mathrm{~kg} \mathrm{CO} /$ tonne $\mathrm{km}$, while shorter-distance trucks are between 16 and 32 tonnes and emit $0.174 \mathrm{~kg} \mathrm{CO}_{2} /$ tonne $\mathrm{km} \mathrm{[17].}$

\section{Choosing Scenarios}

In the real case which the study is based on, several valorisation alternatives of the stillage have already been performed. More than half of the stillage flow leaves as fodder, a third goes to the local biogas plant for vehicle fuel production, and the rest is transported to biogas plants further away or is used directly as fertiliser. These alternatives are feasible and also backed by a Swedish study on the uses of food industry waste [10]. Niklasson [10] also mention the possibility for incineration, which is included in this study as 
the municipal waste incineration plant is situated next door to the biorefinery. In addition to the local and distant biogas plant for vehicle fuel, a final scenario where the local biogas plant produces heat and power is assessed.

Due to Swedish legislation, a landfill option is not evaluated as it is banned to landfill organic materials. The results for the biogas-to-heat-and-power scenario will also be country specific, as the Swedish power generation is close to emission neutral and relatively cheap [18].

\section{Evaluating Aspects}

\section{Greenhouse Gas Emissions}

The greenhouse gas emissions (GHG) are estimated with a life cycle analysis (LCA). Included in the calculations are the transportation of stillage, the emissions from further processing of the stillage and the distributions of the final products. $\mathrm{N}_{2} \mathrm{O}$ emissions are included and converted to $\mathrm{CO}_{2}$-eq where biofertiliser or stillage has been applied to soils; in the results, they are presented in the production emissions. Data regarding $\mathrm{N}_{2} \mathrm{O}$ emissions are taken from the IPCC guidelines for national GHG inventories [19]. Methane emissions from the spreading of fertiliser are assumed to be negligible [20] but are included when it comes to methane slippage in biogas production. The functional unit in this LCA is 1 tonne of stillage treated. The system boundaries start at the back gate of the biorefinery until the use of the final products, and emissions caused by animals eating fodder are not included. Cradle-to-back gate is excluded in the assessment, as the emissions from the biorefinery will be the same for all compared cases. Biomaterials which are combusted count as zero emission, as it can be assumed their $\mathrm{CO}_{2}$ content is neutral due to the short carbon cycle. As an allocation method, system expansion has been used (recommended by ISO 14040). In system expansion, it is assumed that a product produced in the scenario replaces another product. This replaced product would have had an impact which is now avoided and shows up as a negative impact on the results. The specific products which are replaced in each scenario are chosen in regard to the product of the scenario; these are listed in Table 1.

\section{Energy Balance}

Energy balance is an estimation of energy needs in the scenarios and energy generated per tonne of stillage in the scenarios. The system boundaries are again set from the back gate of the biorefinery to final use of the product. Energy needs mainly come from transportation and production processes of the stillage. Energy need for the spreading of fertiliser is neglected due to the small amount of energy needed. The energy generated is estimated based on the energy content of the specific products. The results show energy need, and generation divided into electricity, heat and fuel. As fuels are a more highly valued form of energy than for example heat [21], the amount of energy should not be compared equally. This study does not consider the difference in the estimations but presents the different energy forms individually in the results.

\section{Finances}

The estimations for the financial assessment are based on cost and income, which the alternative valorisation brings to the biorefinery company. Data is based on interviews with the biorefinery, a biogas plant and the incineration plant. From those, information regarding transportation costs and

Table 1 Scenario information

\begin{tabular}{|c|c|c|c|c|c|}
\hline Scenario & Products & Avoided products & Actors & \multicolumn{2}{|l|}{ Assumptions } \\
\hline 1. Fodder & Stillage fodder & Swedish pig fodder & Animal farms & \multicolumn{2}{|l|}{$\begin{array}{l}\text { - Transport distance } \\
\text { - Pig fodder }\end{array}$} \\
\hline 2. Fertiliser & Stillage fertiliser & Mineral fertiliser & Agricultural farms & \multicolumn{2}{|c|}{$\begin{array}{l}\text { - Transport distance } \\
\text { - Characteristics of swine manure } \\
\text { - Neglect impact from fertiliser distribution }\end{array}$} \\
\hline 3. Incineration & Stillage for energy & $\begin{array}{l}\text { Municipal solid waste } \\
\text { (MSW) for energy }\end{array}$ & $\begin{array}{l}\text { Municipal combined } \\
\text { heat and power } \\
\text { plant }\end{array}$ & \multicolumn{2}{|c|}{$\begin{array}{l}\text { - Pump energy is neglected } \\
\text { - Energy content } \\
\text { - Temperature of stillage }\end{array}$} \\
\hline $\begin{array}{l}\text { 4. Local biogas as } \\
\text { vehicle fuel }\end{array}$ & $\begin{array}{l}\text { Biogas fuel and } \\
\text { biofertiliser }\end{array}$ & $\begin{array}{l}\text { Gasoline and mineral } \\
\text { fertiliser }\end{array}$ & Local biogas plant & \multirow{3}{*}{$\begin{array}{l}\text { - No co-digestion } \\
\text { - Nutrient-content } \\
\text { - Neglected impact of } \\
\text { fertiliser distribution } \\
\text { - No reject fraction }\end{array}$} & - Transport distances \\
\hline 5. Local biogas CHP & $\begin{array}{l}\text { Heat and power and } \\
\text { biofertiliser }\end{array}$ & $\begin{array}{l}\text { Mean Nordic electric- } \\
\text { ity, heat and mineral } \\
\text { fertiliser }\end{array}$ & Local biogas plant & & $\begin{array}{l}\text { - Ratio heat vs. power } \\
\text { - Grid is available }\end{array}$ \\
\hline $\begin{array}{l}\text { 6. Distant biogas as } \\
\text { vehicle fuel }\end{array}$ & $\begin{array}{l}\text { Biogas fuel and } \\
\text { biofertiliser }\end{array}$ & $\begin{array}{l}\text { Gasoline and mineral } \\
\text { fertiliser }\end{array}$ & Distant biogas plant & & - Transport distances \\
\hline
\end{tabular}

The three last scenarios connected to biogas solutions have several assumptions in common, and thus were combined into one column 
sales price of the stillage is collected. Interviewees mention which scenarios result in approximately the same income or which came with a cost. Financial data is sensitive, so specific numbers are rarely given. If large spans are provided, averages are used. As transportation cost is a large part of the cost related to stillage, the transportation distances are important for possible profit for the biorefinery. The results in this article are normalised to protect the involved actors. The stillage sell price for the biogas-as-vehicle fuel scenario has been set as the normalising value, and thus 1 , in the results.

\section{Nutrients}

The nutrient aspect is evaluated to illustrate the possibility to replace mineral fertiliser with alternative fertiliser. The local nutrient perspective is important, as it reduces transportation and environmental impact compared to external fertilisers. Analyses of the stillage are performed based on nitrogen ( $\mathrm{N}$-tot), ammonium $\left(\mathrm{NH}_{4}\right)$ and phosphorus (P-tot) content. This study uses $\mathrm{NH}_{4}$ and P-tot in the results. $\mathrm{NH}_{4}$ is chosen as it is a compound more accessible to plants and the concentration increases after anaerobic digestion [22] and therefore provides different outcomes for fertiliser and biogas scenarios. P-tot accounts for both organic and inorganic forms of phosphorous and will be used in the assessment, as the uptake of phosphorus depends more on the type of soil than the composition of phosphorus [23].

The nutrient recycling is illustrated by comparing the nutrient content in the stillage or biofertiliser (digestate) to the amount of nutrients required to grow the wheat, which is originally used for the biorefinery production. The total need for nutrients to grow the required amount of winter wheat is estimated through common data about wheat fields in Sweden. An estimated 16,000 hectares are needed to produce the particular amount of wheat. The specific soil classification in the area of western Sweden is III [24]. This means that the nutrients required to grow wheat in those soils are around $15 \mathrm{~kg} \mathrm{P} / \mathrm{ha} \mathrm{[} \mathrm{[25],} \mathrm{p.} \mathrm{52],} \mathrm{and} 175 \mathrm{~kg} \mathrm{~N} / \mathrm{ha}$ [ [25], p. 31]. We assume the nitrogen in mineral fertiliser is comparable to $\mathrm{NH}_{4}$ as stated by Björnsson et al. [26].

\section{Scenario Descriptions and Data Collection}

The data regarding the scenarios mainly comes from interviews with the involved biogas plant, incineration plant and biorefinery. Additional data and data for the system expansions are gathered from existing literature. Data and calculations can be found in Online Resource 1. In each scenario, it is assumed that the full amount of stillage is used within the set boundaries. In Table 1 a summary of the scenarios is made regarding produced products, avoided products, involved actors and assumptions for each scenario.

\section{Fodder}

The stillage will be directly used as a wet fodder. Transports are therefore required to deliver to the animals in the nearby region, and according to interviews, $50 \mathrm{~km}$ is the mean distance to drive with the fodder to assure that income is higher than cost. The replaced product in the system expansion is assumed to be a Swedish-produced pig fodder, as there are known fodder factories situated nearby the studied town and pigs are the main target for stillage as fodder. The comparison is based on the average protein content of chosen fodders from a fodder producer [27]. This leads to a replacement of approximately $150 \mathrm{~kg}$ usual pig fodder per tonne of stillage. Financial information is based on interviews with representatives from the biorefinery. They claim that the fodder customer is charged with the transport costs as well as a payment for the stillage. No nutrients will be considered recirculated, as our system boundaries end when the fodder is delivered to the animals.

\section{Fertiliser}

In this scenario, the stillage will be used as fertiliser directly by farmers, which is feasible according to [28]. According to interviewed farmers, there are some problems regarding sedimentation and plant damage when distributing stillage as fertiliser. Alotaibi and Schoenau [13] compare the characteristics of thin stillage to be similar to swine manure, which is used in the estimation of $\mathrm{N}_{2} \mathrm{O}$ emissions. The average distance to the farms is set at $20 \mathrm{~km}$. The product replaced in the system expansion will be imported mineral fertiliser transported by truck from $360 \mathrm{~km}$ away; this distance is set to possibly cover a longer ferry trip in combination with a truck, as the origin of mineral fertiliser is not known. The comparison with mineral fertiliser is based on one macronutrient at a time. $\mathrm{NH}_{4}, \mathrm{P}$ and $\mathrm{K}$ in the alternative fertilisers are compared to $\mathrm{N}, \mathrm{P}$ and $\mathrm{K}$ in mineral fertilisers, and greenhouse gas emissions are based on data from [26, 29]. Transports will be made to the farms, and according to interviews, it is most likely the biorefinery which will pay for these. There exist analyses of the stillage content as a fertiliser by the biorefinery, and therefore the average ammonium content is approximately $0.7 \mathrm{~kg} \mathrm{NH}_{4} /$ tonne and phosphorus $0.4 \mathrm{~kg}$ P-tot/tonne of wet stillage. The replaced amount of mineral fertiliser is approximately $3 \mathrm{~kg}$, based on the ammonium content. 


\section{Incineration CHP}

This scenario will incinerate the stillage in the municipal combined heat and power plant (CHP). The stillage is assumed to be pumped from the biorefinery through pipes to the CHP, as they are situated within a few hundred meters of each other. The installation of new piping is not included in the calculations. For feasibility, the stillage is assumed to be sprayed on the regular waste, moisturising it. The greenhouse gas and energy calculations are based on the energy content in the stillage and the water content when the stillage is 50 degree Celsius. The energy content in the stillage is assumed to be $20.24 \mathrm{MJ} / \mathrm{kg} \mathrm{DM} \mathrm{[30],} \mathrm{although} \mathrm{the} \mathrm{charac-}$ teristics might differ in this case the energy content of the dry matter is assumed to be similar. The CHP plant's data has been used in the calculations regarding emissions and energy generation. In the system expansion, it is assumed the stillage replaces municipal solid household waste (MSW) from the region to generate the specific amount of energy. The financial information received claimed that this concept will be expensive for the provider of the stillage when the amount is so large. Nutrient recycling is not relevant in this scenario, as the ashes containing the nutrients are contaminated from other wastes incinerated.

\section{Local Biogas as Vehicle Fuel}

In this scenario, it is assumed that $100 \%$ of the stillage is used in the biogas plant. The amount of biogas produced for sales would be $687 \mathrm{MJ} /$ tonne of stillage based on a VS content of $7.8 \%$ in the wet stillage; it can also be written as $19.14 \mathrm{Nm}^{3} /$ tonne of stillage. In the system expansion, it is assumed that mineral fertiliser and fossil fuels are replaced by the biofertiliser and biogas. Most of the greenhouse gas emissions are connected to transportation. The biogas plant is situated $3 \mathrm{~km}$ from the biorefinery and receives the materials by truck. The biofertiliser produced in the biogas plant is used by farmers in the region. According to interviews, $80 \%$ of the farmers are situated within $20 \mathrm{~km}$, and this is the reason why all fertiliser in the different scenarios is assumed to travel, on average, $20 \mathrm{~km}$. The distance of transporting the biogas by truck is set at $130 \mathrm{~km}$. Heating required in the biogas plant is generated by the internal use of methane gas, which is subtracted from the amount of methane generated. The large energy demand in the biogas for fuel process comes from the facility for upgrading the raw gas to biomethane, and the biogas plant pays the biorefinery for the stillage. Regarding nutrient recycling, the estimations are based on the nutrient content of the untreated stillage. According to Berglund [31], approximately $70 \%$ of N-tot is in the form of $\mathrm{NH}_{4}$ in biofertiliser. In accordance with stillage analyses, the nitrogen content is $3.3 \mathrm{~kg} \mathrm{~N}$-tot/tonne; see the Online Resource 1, for further calculations. P-tot is assumed to remain the same in the raw stillage and the biofertiliser. The replaced amount of mineral fertiliser is assumed to be about $5 \mathrm{~kg} /$ tonne of wet stillage based on the $\mathrm{P}$ content, as this was the limiting nutrient. When replacing gasoline, $0.74 \mathrm{~kg}$ biogas $/ \mathrm{L}$ gasoline is assumed [32], and emissions on a well-to-wheel perspective are $2.94 \mathrm{~kg} \mathrm{CO}_{2} / \mathrm{L}$ gasoline [33].

\section{Local Biogas CHP}

This scenario is based on the idea that the local biogas plant will generate heat and power rather than producing vehicle fuel. This means all plant specific information will remain the same for the biogas plant, as in "Local Biogas as Vehicle Fuel" section. The products from this facility will be connected to the local district heating and electricity networks and the energy demand is lower than in "Local Biogas as Vehicle Fuel" section, as no upgrading of the raw gas is required. When applying system expansion on this scenario, Mean Nordic electricity, heating from the local municipal waste incineration plant and mineral fertilisers are replaced. Regarding the energy generation, it is assumed that $43.3 \%$ electricity, $43.7 \%$ heat and $13 \%$ losses are generated from the biogas [34]. In the financial assessment, the willingness to pay for the substrate is assumed to be relative to the difference in price between electricity and fuel gas. In this case, $1 \mathrm{kWh}$ of fuel biogas costs approximately 1.38 SEK (0.13 EUR) and $1 \mathrm{kWh}$ of electricity 0.35 SEK (0.033 EUR), which is approximately four times better payment for fuel than electricity (see [35] and [36]). The nutrient data is the same as in "Local Biogas as Vehicle Fuel" section.

\section{Distant Biogas as Vehicle Fuel}

If there is no biogas plant nearby, there would be a possibility to transport stillage to other biogas plants further away. In this case, several biogas plants have been identified as possible recipients for distances of 60-180 km, where an average of $120 \mathrm{~km}$ has been assumed in the calculations. Regarding the biogas plant itself, it is assumed to have the same characteristics as the one in "Local Biogas as Vehicle Fuel" section. Regarding the cost, we assume the payment is the same from the biogas plant but that the biorefinery will pay for the transport, which is more expensive for longer distances. Nutrient content will be estimated for this scenario, but it will not contribute to local nutrient recycling. 
(a) GHG emissions ( $\mathrm{kg} \mathrm{CO}_{2}$-eq/tonne)

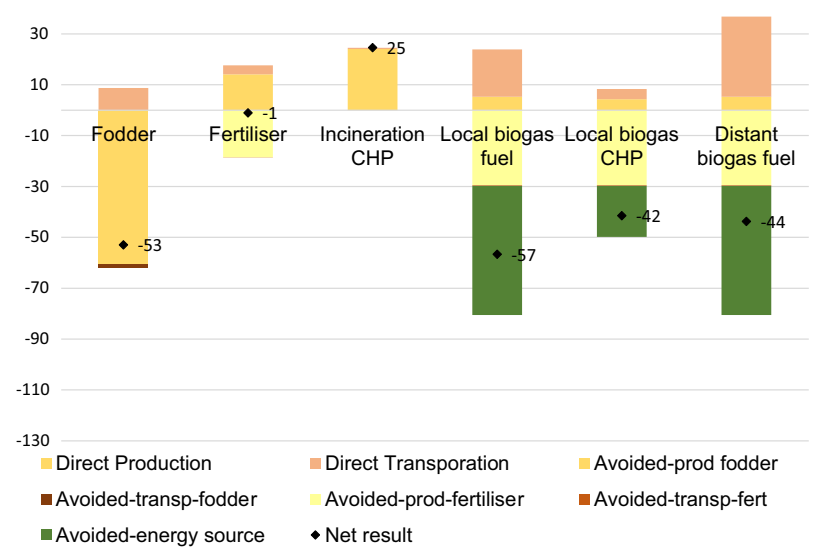

(c) Financial results

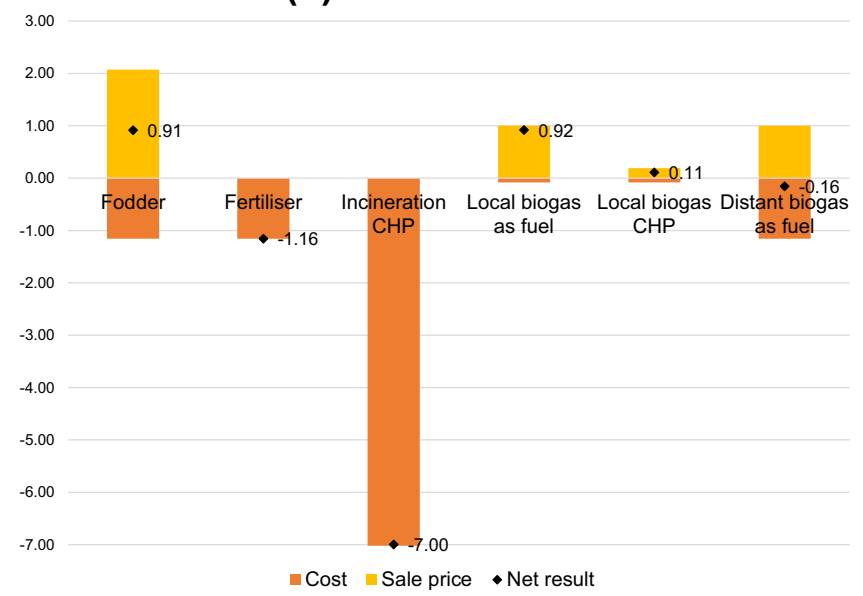

Fig. 2 Results. a Greenhouse gas emissions are presented in $\mathrm{kg}$ $\mathrm{CO}_{2}$ eq/tonne stillage and avoided emissions are due to applied system expansion. b The energy need and generation for the different scenarios in MJ/tonne of stillage. $\mathbf{c}$ The financial assessment, where the income or cost for the biorefinery is presented with normalised val-

\section{Results}

This section will present the results of the calculation made on GHG emissions, energy balance, financial situation and local nutrient recycling.

In Fig. 2a, the climate impact of the alternative valorisation methods is shown. The biogas-for-fuel scenarios have the most negative emissions, as emissions from gasoline and mineral fertilisers are avoided. They do have high direct emissions, though, due to long transport distances and the facility for upgrading. This means that the fodder scenario is as good as biogas for fuel when looking at the net GHG emissions. As the fodder scenario does not have long transports, the direct emissions are less than $10 \mathrm{~kg} \mathrm{CO}_{2}$ eq/tonne of stillage. (b) Energy use or production (MJ/tonne)

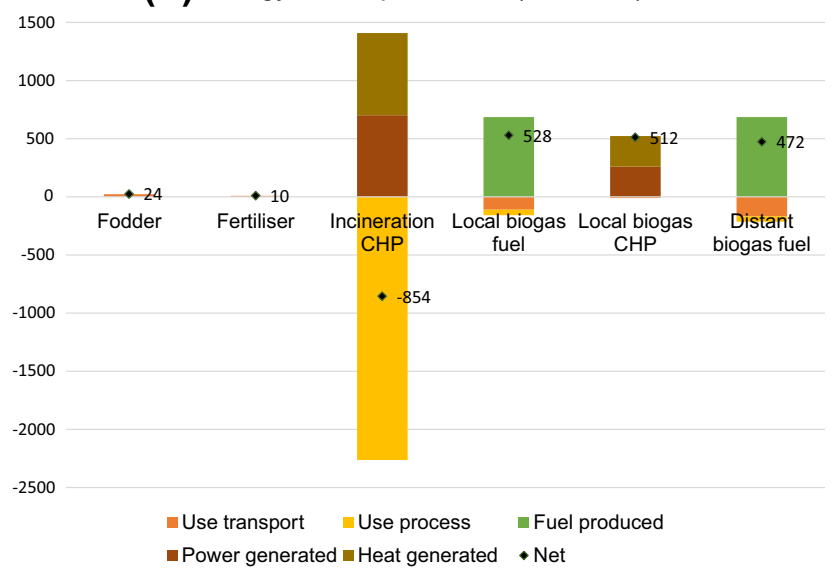

(d) Share of nutrient supply to local wheat fields

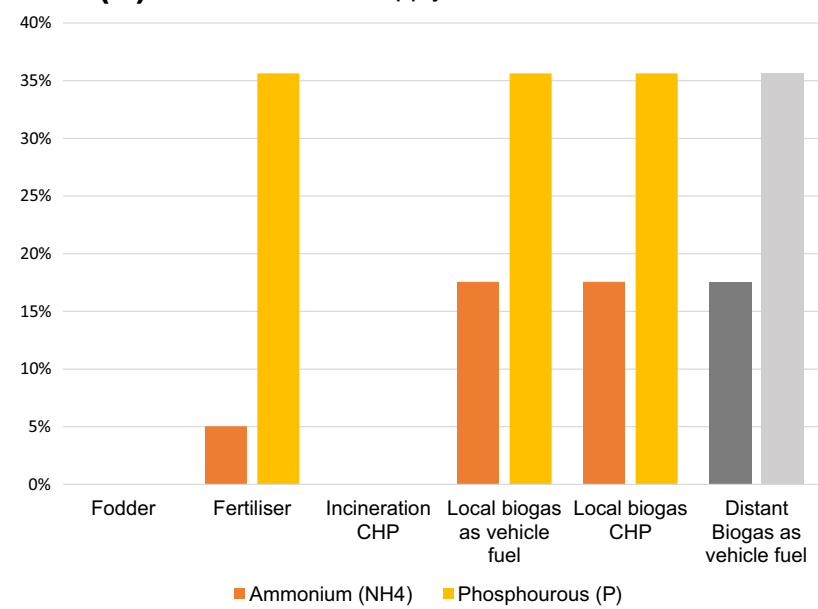

ues. d The share of nutrients that are recirculated to the wheat fields providing the raw materials; the results of the distant biogas plant are greyed out, as it does not contribute to the local nutrient recycling. a-c Net values are marked with a black diamond; this is the result when positive and negative values are summarised

Due to the high water content of the stillage (92\%), incineration is both expensive and energy demanding as a valorisation method. The positive GHG emissions are due to the energy from household waste required to evaporate the water in the stillage. The three biogas scenarios receive the best results in regard to energy generation and nutrient recycling in this Swedish context (Fig. 2b, d). The biogas scenarios benefit from their potential energy generation and the nutrient-rich biofertiliser, which compared to the direct fertiliser application scenario replaces more mineral fertiliser and thus avoids more GHG emissions. It is the increased amount of ammonium after digestion which results in better nutrient recycling in the biogas scenarios (Fig. 2d). While the biogas for fuel scenarios generate the most energy (see Fig. 2b), they also require the most energy, if incineration is excluded. When looking at energy demand the picture is 
different, as the fodder and fertiliser scenarios do not need any process energy which the biogas scenarios do. Among the biogas scenarios, the fuel production requires the most energy for the upgrading of raw gas to fuel gas. The financial results in Fig. 2c show the potential income for the biorefinery. The biorefinery often has to pay transportation cost which results in lower revenue for long transport alternatives. Therefore, financially, the local biogas for the fuel and fodder scenarios are equally good. The generation of heat and power in the biogas plant would also result in a small income for the biorefinery. The distant biogas plant and the use as fertiliser is a cost for the biorefinery, but if no other options are available, they might be used.

In general, we see that transportation has a great impact on the results. It increases emissions, energy use and cost. When assessing potential alternatives, the distances to customers are therefore important.

\section{Sensitivity Analysis}

Parameters which are further investigated in this sensitivity analysis are either connected to assumptions regarding parameters used in the assessment or identified as a critical factor which will alter the whole project setup. Not all scenarios are assessed in the sensitivity analysis; only the ones affected the most by the chosen parameters are assessed.

\section{Assumptions}

Commonly assumed parameters affecting the results are transportation and energy aspects. Therefore, three of the assessments focus on this. The sensitivity analysis of transportation is replacing diesel trucks by trucks running on biogas with exhaust emissions assumed to be part of the natural carbon cycle. The energy evaluation is also made to create a more general discussion point regarding possible outcomes due to the origin of the energy used. The source of energy in the original results is the Nordic electricity mix, which has lower emissions than for example the EU electricity mix or coal-based energy sources [18]. The scenarios, therefore, are re-evaluated with the emissions from those energy sources. Another assumption which is very specific for this Swedish case is the origin of fodder. A common fodder replacement is soybased and imported from far away, in contrast to the local wheat-based fodder used in the assessment. The estimations are done on greenhouse gas emissions to narrow the sensitivity analysis down. Qualitative comments are made regarding the other aspects evaluated earlier in the article.

The energy source chosen for this article was the Nordic electricity mix. If the plant were to be situated at a location where coal-produced electricity or the EU electricity mix is common, the GHG emissions will increase for the scenarios with the largest electricity need, which are the biogas plants requiring technology for upgrading. On the other hand, the local biogas CHP scenario will improve environmentally as electricity generation from other sources is replaced by the renewable electricity generated from biogas. If the electricity replaced would be coalbased it would avoid up to 7 times higher $\mathrm{CO}_{2}$-eq emissions compared to the current scenario [37]. The EU mix is estimated at a 2014 value of $275.9 \mathrm{~g} \mathrm{CO}_{2}$-eq/kWh [38]. In Fig. 3, the local biogas CHP scenario becomes the best alternative regarding $\mathrm{GHG}$ emissions when replacing coal, but no significant difference is seen when applying the EU electricity mix. Depending on the price of electricity, the costs are influencing the different scenarios. The fodder scenario does not have an electricity variable, and thus the estimations remain the same as in the original scenario.

If all transports in the scenarios were run on biogas instead of diesel, the results in Fig. 3 show how climate
Fig. 3 Sensitivity analysis of greenhouse gas emissions for the scenarios fodder, fertiliser, local biogas as fuel and local biogas CHP scenarios

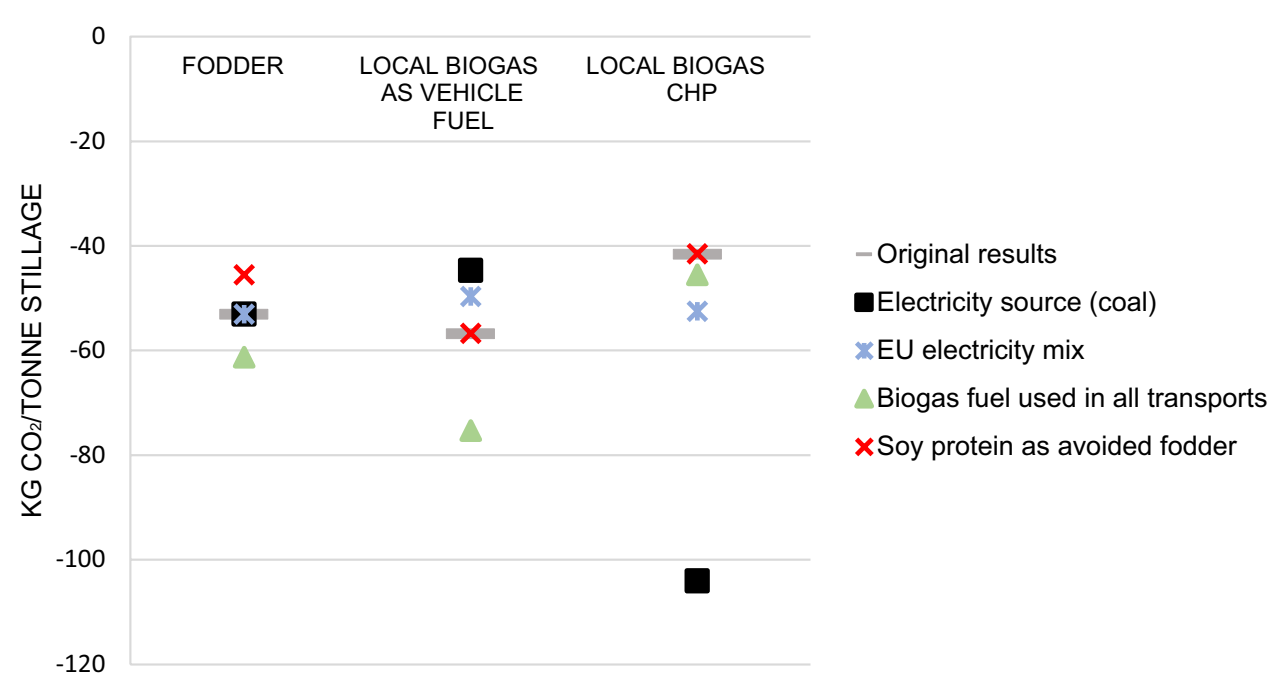


impact improves for all scenarios. Scenarios with longer transport distances, the biogas-for-fuel scenario, for example, has both transportation of stillage to the plant and transportation of biogas to fuelling stations, and the reduced impact is larger than for scenarios with shorter distances.

If changing the replaced fodder to imported soybean fodder where the emissions are $810 \mathrm{~kg} \mathrm{CO}_{2}$-eq/tonne fodder [37] and protein content $470 \mathrm{~g} / \mathrm{kg}$ fodder (see [39] and [40]), the replaced amount of fodder by one tonne of stillage becomes lower and the avoided emissions are lower than for Swedish fodder per replaced tonne of stillage. When transportation by truck is longer than $4500 \mathrm{~km}$, the avoided emissions for soy fodder are larger than for the Swedish local fodder.

\section{Critical Factor}

A critical factor to assess is the protein content of the stillage. As it is confirmed, the protein content in the assessed stillage is much lower than in other studies, and it is interesting to see how the results change due to the protein content.

If we assume the stillage has a $41 \%$ protein content, which is a high value [14], the net result for the fodder scenario becomes almost three times better than today, that is, $138 \mathrm{~kg}$ of carbon dioxide per tonne of stillage is avoided in this assessment when more conventional fodder can be replaced. The biogas scenarios also improve as it is assumed that $\mathrm{NH}_{4}$ content in the biofertiliser is linear to the protein content. The increased amount of nutrients can replace a larger share of the mineral fertilisers, thus leading to more avoided emissions. In this case, the local-biogas-for-fuel scenario increase to 80 and local-biogas-for-heat-and-power scenario increase to $65 \mathrm{~kg}$ of net $\mathrm{CO}_{2}$ avoided emissions per tonne of stillage. Higher protein content could possibly increase biogas exchange in the reactors [41], but this is not accounted for in this assessment. With higher protein content, the potential income could probably increase for all scenarios, and the nutrient circulation will also improve for the fertiliser and biogas scenarios.

\section{Discussion}

The results point toward biogas solutions or direct use as fodder as the two most attractive valorisation alternatives for stillage from an environmental and financial perspective. In other studies, for instance, Bernesson and Strid [14], fodder alternatives often come out as the preferable option in most impact categories, with biogas solutions closely behind. Such fodder-favouring studies often display higher protein content than this study. The lower protein content is due to the extraction of separate proteins in the earlier processes. Lower protein content implies lower amounts of replaced fodder and fertiliser, which influence the results of the study. A study by Sajbrt et al. [42] reveals high cost for implementing the fodder alternative since it involved drying, while this study uses the wet stillage directly as fodder, as it is mixed with other fodder components by the farmers. The benefit of drying the fodder is that it makes transports more efficient and increases the potential for higher income for the biorefinery. It could still, however, be hard to financially motivate since it is a low-priced by-product.

The design of the scenarios is important for the results. The sensitivity analysis shows how the biogas CHP option improves when it substitutes coal-based electricity rather than the Nordic electricity mix. The performance of the distant biogas scenario would improve if there was a local biogas market because the transportation of the biogas would be reduced. Also, the incineration scenario could be improved if smaller amounts of stillage were treated. Smaller amounts of stillage could be incinerated with better performance when mixed with drier fuels. This would result in lower costs for the biorefinery as well as a better overall energy balance for the incineration plant.

All of the biogas scenarios could benefit from co-digestion for increased biogas exchange [43]. Applying such data to this study would lead to higher biogas fuel generation and more avoided products for the biogas scenarios. A combination of different valorisation alternatives could be a possible option, implying improved redundancy of the system. One such interesting combination is if the fodder scenario is expanded to include biogas production from the manure produced by the animals. Nutrients in digested manure are often more available than applying manure directly [44]. This would improve the valorisation of the wheat.

This article tries to emphasise the importance of improved valorisation of low-quality by-products in biorefinery settings. Optimising the value output from one raw material might become crucial in the future circular and bio-based economy with resource constraints. This could, for example, be done through technological improvements and pretreatment of biomass leading to more product extraction (see $[45,46])$. The importance of valorisation in biorefineries is discussed by Trakulvichean et al. [47], who have studied the valorisation of cassava cellulosic waste to increase value in starch factories. Their environmental and financial assessment concludes that using this waste for biogas production generating heat gives the best net present value, including environmental costs. This finding, however, is valid in another energy system context than this study. Other studies focus on the potential of low-quality by-products, such as FitzPatrick et al. [48], who studied the forest industry. They conclude that there is a potential for high-value product extraction from low-quality bio-waste streams if hemicellulose and lignin are separated and treated individually. 
They emphasise the importance of valorising biomass waste, which is also a central finding in this study. When assessing alternative valorisations in biorefinery settings it can be relevant to consider the economic conditions, distance to raw material, other entities and market as well as know-how of a biorefining production system [49].

It is likely that as more highly valued products are extracted from biomass, more low-value by-products will be also generated, calling for further treatment solutions. Biogas solutions have a potential to contribute in this regard as they are versatile [50] and add value to industrial systems [3], almost regardless of the quality of the by-product streams. Biogas solutions in this study have the advantage of performing well in both environmental and financial categories. There are also reports from actors in the studied setting about further added value, which is not included in this assessment. Some of this added value can be identified when you assume a scenario without biogas solutions. Market opportunities for stillage would be restricted, as the fodder market would become saturated and the biorefinery will have to pay more for transportation. Fewer vehicles would use renewable and clean fuel, and the organic farmers surrounding the biorefinery plant would not be able to get hold of renewable fertilisers as cheaply and easily. Biogas solutions improve performance and reduce environmental impact for several systems around the actual facility as suppliers, customers, farmers, municipality and private persons are affected by their activities.

\section{Conclusion}

This article has assessed which valorisation alternatives of stillage from ethanol production are the most beneficial environmentally and financially for a biorefinery network. The study focused on an ethanol plant and the actors required for valorising the low-quality stillage. The results and discussion conclude that biogas solutions are viable both for environmental and financial reasons, especially if the stillage or biorefinery by-product is of low-quality and therefore loose value as a fodder which otherwise can be a good alternative too according to the results. This study has also contributed with an evaluation of local nutrient recirculation of each valorisation alternative, where the biogas plant studied, return the most nutrients to local farmers which improve overall sustainability of the studied system.

Acknowledgements This research has been funded by the Biogas Research Center (BRC), which is in turn funded by the Swedish Energy Agency, partners and Linköping University.

Open Access This article is distributed under the terms of the Creative Commons Attribution 4.0 International License (http://creativeco mmons.org/licenses/by/4.0/), which permits unrestricted use, distribution, and reproduction in any medium, provided you give appropriate credit to the original author(s) and the source, provide a link to the Creative Commons license, and indicate if changes were made.

\section{References}

1. Nattrass, L., Biggs, C., Bauen, A., Parisi, C., Rodriguez-Cerezo, E., Barbero, M.G.: The EU Bio-Based Industry: Results from a Survey. Joint Research Centre (Seville site) (2016)

2. Sonnenberg, A., Baars, J., Hendrickx, P.: IEA Bioenergy Task 42 Biorefinery (2007)

3. Hagman, L., Blumenthal, A., Eklund, M., Svensson, N.: The role of biogas solutions in sustainable biorefineries. J. Clean. Prod. 172, 3982-3989 (2018)

4. Martin, M., Parsapour, A.: Upcycling wastes with biogas production: an exergy and economic analysis. In: Venice 2012: International Symposium on Energy from Biomass and Waste (2012)

5. Langeveld, H., Sanders, J., Meeusen, M.: The Biobased Economy: Biofuels, Materials, and Chemicals in the Post-oil Era. Earthscan, London (2012)

6. de Ridder, M.: Risks and Opportunities in the Global Phosphate Rock Market: Robust Strategies in Times of Uncertainty. The Hague Centre for Strategic Studies, Den Haag (2012)

7. Himmelblau, D.M., Riggs, J.B.: Basic Principles and Calculations in Chemical Engineering. FT Press, Upper Saddle River (2012)

8. Spångberg, J.: Recycling Plant Nutrients from Waste and ByProducts, vol. 2014. Sveriges lantbruksuniv, Acta Universitatis agriculturae Sueciae, Uppsala (2014)

9. Peng, W., Pivato, A.: Sustainable management of digestate from the organic fraction of municipal solid waste and food waste under the concepts of back to earth alternatives and circular economy. Waste Biomass Valoriz. (2017). https://doi.org/10.1007/s1264 9-017-0071-2

10. Niklasson, C.: Organiskt avfall och biprodukter från livsmedelsoch fodermedelsindustri. Länsstyrelsen i Västra Götalands län, Miljöskyddsenheten, Rapport 2010, 64 (2010)

11. O'Brien, F.A.: Scenario planning-lessons for practice from teaching and learning. Eur. J. Oper. Res. 152(3), 709-722 (2004)

12. Börjeson, L., Höjer, M., Dreborg, K.-H., Ekvall, T., Finnveden, G.: Scenario types and techniques: towards a user's guide. Futures 38(7), 723-739 (2006)

13. Alotaibi, K.D., Schoenau, J.J.: Greenhouse gas emissions and nutrient supply rates in soil amended with biofuel production byproducts. Biol. Fertil. Soils 49(2), 129-141 (2012)

14. Bernesson, S., Strid, I.: Svensk spannmålsbaserad drank. Uppsala, Rapport 32, September 2011

15. Weinberg, J., Kaltschmitt, M.: Greenhouse gas emissions from first generation ethanol derived from wheat and sugar beet in Germany-Analysis and comparison of advanced by-product utilization pathways. Appl. Energy 102, 131-139 (2013)

16. Wood, B.M., et al.: Industrial symbiosis: corn ethanol fermentation, hydrothermal carbonization, and anaerobic digestion. Biotechnol. Bioeng. 110(10), 2624-2632 (2013)

17. Wernet, G., Weidema, B., Bauer, C., Steubing, B., Reinhard, J., Moreno-Ruiz, E.: The ecoinvent database version 3 (part I): overview and methodology. Int. J. Life Cycle Assess. 21(9), 1218 $1230(2016)$

18. IEA: Nordic Energy Technology Perspectives 2016 (2016)

19. Eggleston, H.S.: Intergovernmental Panel on Climate Change, National Greenhouse Gas Inventories Programme, and Chikyū 
Kankyō Senryaku Kenkyū Kikan, 2006 IPCC guidelines for national greenhouse gas inventories (2006)

20. Rodhe, L., Baky, A., Olsson, J., Nordberg, Å.: Växthusgaser från stallgödsel- Litteraturgenomgång och modellberäkningar, vol. 402. JTI, Institutet för jordbruks- och miljöteknik, Uppsala (2012)

21. Ohta, T.: Energy Technology: Sources. Systems and Frontier Conversion. Newnes, Amsterdam (2012)

22. Lehtomäki, A., Björnsson, L.: Two-stage anaerobic digestion of energy crops: methane production, nitrogen mineralisation and heavy metal mobilisation. Environ. Technol. 27(2), 209-218 (2006)

23. Tisdale, S.L., Nelson, W.L., Beaton, J.D.: Soil fertility and fertilizers. Macmillan Publishing Company, New York (1985)

24. Söderström, M.: Traditionell markkartering i precisionsodling. Institutionen för mark och miljö Precisionsodling Sverige Precisionsodling och pedometri, Skara (2008)

25. Albertsson, B., Börling, K., Kvarmo, P., Listh, U., Malgeryd, J., Stenberg, M.: Riktlinjer för gödsling och Kalkning 2016. Jordbruksverket (2016)

26. Björnsson, L., Lantz, M., Börjesson, P., Prade, T., Svensson, S.-E., Eriksson, H.: Impact of Biogas Energy Crops on GHG Emissions, Soil Organic Matter and Food Crop Production. Report No 2013:27. The Swedish Knowledge Centre for Renewable Transportation Fuels, f3, Sweden (2013)

27. Edelfoder: Edel-Grisfoder (Online) (2013). http://media6.johan hansson.se/2015/09/EDEL-Gris-2013-14.pdf

28. Alotaibi, K.D., Schoenau, J.J., Hao, X.: Fertilizer potential of thin stillage from wheat-based ethanol production. BioEnergy Res. 7(4), 1421-1429 (2014)

29. Börjesson, P., Tufvesson, L., Lantz, M.: Life cycle assessment of biofuels in Sweden. LUTFD2TFEM-103061-SE1-88. Lund University, Lund (2010)

30. Morey, R.V., Hatfield, D.L., Sears, R., Haak, D., Tiffany, D.G., Kaliyan, N.: Fuel properties of biomass feed streams at ethanol plants. Appl. Eng. Agric. 25(1), 57-64 (2009)

31. Berglund, P.: Biogödselhandbok- Biogödsel från storskaliga biogasanläggningar. Avfall Sverige, Region Skåne, Grontmij AB, Malmö U2010, 11 (2010)

32. Miljöfordon: Gasbil (Online). https://www.miljofordon.se/bilar/ gasbil/. Accessed 24 Apr 2018

33. Swedish Energy Agency: Drivmedel och biobränslen 2015, Mängder, komponenter och ursprung rapporterade i enlighet med drivmedelslagen. Swedish Energy Agency, Stockholm (2015)

34. San Martín, J.I., Zamora, I., San Martín, J.J., Aperribay, V., Eguía, P.: Trigeneration systems with fuel cells. Power 40, 65-85 (2008)

35. Energigas Sverige: Aktuella priser (Online) (2017) http://www. gasbilen.se/Att-tanka-din-gasbil/Aktuella-priser. Accessed 13 Mar 2017

36. Vattenfall: Historik över elpriserna på elbörsen (Online) (2017). https://www.vattenfall.se/elavtal/elpriser/rorligt-elpris/prishistor $\mathrm{ik} /$. Accessed 13 Mar 2017

37. IEA: Power Generation from Coal-Measuring and Reporting Efficiency Performance and $\mathrm{CO}_{2}$ Emissions. International Energy Agency, Paris, 2010

\section{Affiliations}

\section{Linda Hagman $^{1}{ }^{10} \cdot$ Mats Eklund $^{1} \cdot$ Niclas Svensson ${ }^{1}$}

Linda Hagman

linda.hagman@liu.se
38. EEA: Overview of electricity production and use in Europe. European Environment Agency (Online) (2014). https://www. eea.europa.eu/data-and-maps/indicators/overview-of-the-elect ricity-production-2/assessment. Accessed 9 Apr 2018

39. FAO: Protein sources for the animal feed industry (Online) (2004). http://www.fao.org/docrep/007/y5019e/y5019e03.htm. Accessed 9 Apr 2018

40. Flysjö, A., Cederberg, C., Strid, I.: LCA databas för konventionella fodermedel. Miljöpåverkan i samband med produktion (2008)

41. Kovács, E., et al.: Augmented biogas production from proteinrich substrates and associated metagenomic changes. Bioresour. Technol. 178, 254-261 (2015)

42. Sajbrt, V., Rosol, M., Ditl, P.: A comparison of distillery stillage disposal methods. Acta Polytech. 50(2), 63-69 (2010)

43. Westerholm, M., Hansson, M., Schnürer, A.: Improved biogas production from whole stillage by co-digestion with cattle manure. Bioresour. Technol. 114, 314-319 (2012)

44. Risberg, K., Cederlund, H., Pell, M., Arthurson, V., Schnürer, A.: Comparative characterization of digestate versus pig slurry and cow manure-chemical composition and effects on soil microbial activity. Waste Manag. 61, 529-538 (2017)

45. ElMekawy, A., Diels, L., De Wever, H., Pant, D.: Valorization of cereal based biorefinery byproducts: reality and expectations. Environ. Sci. Technol. 47(16), 9014-9027 (2013)

46. Bateni, H., Bateni, F., Able, C., Noori, M.S.: Biorefinery of safflower seeds in a sequential process for effective use of the substrate for biofuel production. Waste Biomass Valoriz. 9, 1-11 (2017)

47. Trakulvichean, S., Chaiprasert, P., Otmakhova, J., Songkasiri, W.: Integrated economic and environmental assessment of biogas and bioethanol production from cassava cellulosic waste. Waste Biomass Valorization 10(3), 691-700 (2017)

48. FitzPatrick, M., Champagne, P., Cunningham, M.F., Whitney, R.A.: A biorefinery processing perspective: treatment of lignocellulosic materials for the production of value-added products. Bioresour. Technol. 101(23), 8915-8922 (2010)

49. Blair, M.J., Cabral, L., Mabee, W.E.: Biorefinery strategies: exploring approaches to developing forest-based biorefinery activities in British Columbia and Ontario. Canada. Technol. Anal. Strateg. Manag. 29(5), 528-541 (2017)

50. Mountraki, A., Tsakalova, M., Panteli, A., Papoutsi, A.I., Kokossis, A.C.: Integrated waste management in multiproduct biorefineries: systems optimization and analysis of a real-life industrial plant. Ind. Eng. Chem. Res. 55(12), 3478-3492 (2016)

Publisher's Note Springer Nature remains neutral with regard to jurisdictional claims in published maps and institutional affiliations.

1 Environmental Technology and Management, Linköping University, 58183 Linköping, Sweden 